\title{
Translation as Creation: Interview with Gao Xingjian ${ }^{1}$
}

\section{Mingxing Wang University of Alberta}

The 2000 Nobel laureate, Gao Xingjian, currently residing in Paris, won the prestigious Nobel prize for literature mainly for his monumental novel Lingshan (Soul Mountain) and dramatic works. While Gao's literary achievements have been highly valued in the West, his translational works from the start of his literary career in China till his sojourn in France (beginning in 1988) appear less known to the readers. The interviewer had the pleasure to have a short talk with Gao on September 10, 2015, during the $5^{\text {th }}$ Congress of Asian and Pacific Studies held at L'Institut National des Langues et Civilisations Orientales (INALCO) in Paris. The conversation was conducted in Chinese and its script translated and edited by the interviewer.

Wang: Thank you for taking the time to talk with me about your work in translation. In my opinion, your literary career has something to do with translation, do you agree?

Gao: It is only true to a certain extent. It is not always so.

Wang: Okay, let's talk a little about your early career as a translator. When you did your undergraduate studies in the Department of French Studies at Beijing Foreign Language Institute (Now Beijing Foreign Studies University) in the early 1960s, did you have any training in translation? Did you translate anything in the school?

Gao: My program didn't offer translation trainings at the time. I didn't translate at the time either. But we enjoyed much freedom in our studies at the department.

Wang: So far as I can remember, in the 1970s, you worked as a French translator firstly at The China International Bookstore, then as a team leader at the French Section of the Journal La Chine en Construction. What did you translate?

Gao: I actually didn't translate much.

\section{Wang: No?}

Gao: No.

1 A brief French version was published in Alternative Francophone, Vol 2, No. 2, 2017. 
Wang: So, when did you start to translate?

Gao: I only started to translate around Mao's death in 1976.

Wang: What did you translate? Did you have any preference in choosing your texts?

Gao: I rendered a lot of items, and I only submitted them for publication when my friends asked me to contribute to their literary journals. At the time, I only chose the items that had not been translated to meet their needs.

Wang: Referring to translation in the 1970s, the prominent poet Bei Dao says in his article, "Translation is a Silent Rebellion", that translation played a significant role in helping him to see his world from a radically different light. Do you think that your translation can be considered as an act of rebellion?

Gao: For him, it might be true. For me, I could get to know the outside world through the French language. I read a lot of things in French.

Wang: When you chose to translate the French plays by Samuel Beckett and Eugene Ionesco, did you have any bilingual identification with these playwrights?

Gao: No.

Wang: In the early 1980s, your short stories were translated into French. Is that so?

Gao: Yes. Paul Poncet, who was a professor of Chinese language and literature, did French translations of my short stories, "In the Park", then "Mother" in the 1980s. But after his sudden death, I asked Professor Noël Dutrait to translate my works into French.

Wang: When Professor Noël Dutrait began to work on your Lingshan (Soul Mountain) in the early 1990s, did you work together?

Gao: I didn't work with him, but I knew what he was doing.

Wang: In addition to the French version of your novel, Lingshan was also translated into Swedish and English in the 1990s. Your Swedish translator, Göran Malmqvist, characterized your language as "pure", while your English translator, Mabel Lee, said that your style in the novel was minimalist. Do you agree with their assessments?

Gao: Minimalist? No. But my language is pure. 
Wang: Relating to the bilingual versions of your plays written in France, Claire Conceison, English translator of your play Ballade Nocturne (Ballade nocturne: libretto for a dance performance in English), said that when she translated your French play into English, she had to take your other plays into consideration and wanted to make her English version cohesive with your other plays. What do you think of it?

Gao: It all depends on my individual plays. Some of them can be cross-referenced together; some of them are not suitable.

Wang: On many occasions, you said that you wanted to use literature as a means to express your individual voice as a writer, but with reference to translation, your individual voice has to be expressed in a different language by a translator. Where is your voice? It seems that your voice has to be stifled.

Gao: ...I only hope that there is a better solution!

Wang: What about your own translational approach? In 2013, you gave a talk on translation at the Heng Seng Management College in Hong Kong. It seems to me that the translation model of the Chinese master translator, Lin Shu $(1852-1924)$ is your favorite model. So, did you intend to translate like what Ezra Pound did?

Gao: Yes. 